\title{
Arterial Stiffness and Coronary Artery Disease
}

\author{
Bruno Finkler ${ }^{1}$, Bruna Eibel ${ }^{1,2}$, Weimar Sebba Barroso ${ }^{3}$ and Eduardo Barbosa ${ }^{4 *}$ \\ ${ }^{1}$ Instituto de Cardiologia RS/Fundação Universitária de Cardiologia (IC/FUC), Brazil \\ ${ }^{2}$ Centro Universitário Faculdade da Serra Gaúcha (FSG), Brazil \\ ${ }^{3}$ Liga de Hipertensão/Universidade Federal de Goiás (UFG), Brazil \\ ${ }^{4}$ Liga de Hipertensão de Porto Alegre/RS, Brazil
}

Submission: July 16, 2019; Published: July 31, 2019

*Corresponding author: Eduardo Barbosa, Liga de Hipertensão de Porto Alegre, Costa 30 cj 408 Porto Alegre, Brazil

\section{Abstract}

Atherosclerosis is a chronic inflammatory response involving lipid accumulation, smooth cell proliferation, cellular apoptosis, necrosis, fibrosis and local inflammation. It is a leading cause of death in adults. Arterial stiffness results from a degenerative process affecting the extracellular matrix of elastic arteries under the effect of age and cardiovascular risk factors (such as diabetes, hypertension, smoking and sedentary lifestyle). Cardiovascular risk factors are associated with both the atherosclerotic process and arterial stiffness; these conditions have an age-related progression and develop at similar sites of the arterial tree. Assessment of arterial stiffness has emerged as a key tissue biomarker for cardiovascular risk stratification and estimation of biological age. This review study aimed to describe the pathophysiology of arterial stiffness, indirect measurement methods and clinical implications for the management of atherosclerotic disease [1-4].

Keywords: Arterial stiffness; Coronary artery; Hypertension; Chronic inflammatory

Abbreviations: BP: Blood Pressure; CAD: Coronary Artery Disease; PWV: Pulse Wave Velocity; CAFE: Conduit Artery Functional Endpoint; ASCOT: Anglo-Scandinavian Cardiovascular Outcomes Trial; CCTA: Coronary Computed Tomography Angiography; CAVI: Cardio-Ankle Vascular Index; PWV: Pulse Wave Velocity; AIx: Augmentation Index; AP: Augmentation Pressure

\section{Aortic Stiffness}

Increased aortic stiffness is an established vascular condition that occurs through the normal biological evolution. Recent evidence shows it may be associated with atherosclerotic disease when arterial beds such as aortic arch and its branches are affected at an earlier stage [5].

The arterial network, primarily large vessels, is a compliant system that expands and contracts in response to pressure changes [6] to accommodate the blood during cardiac systole and keep the blood flow at the periphery during diastole [5].

In addition to aging, aortic stiffening may be accelerated in the presence of several conditions including systemic arterial hypertension, insulin resistance and diabetes mellitus, smoking, atherosclerosis and chronic kidney disease [7-11].

Reduced aortic compliance has also been associated with other factors such as genetic predisposition, inflammation and infection [12] (Figure 1). A decrease in arterial compliance plays a role in the dysfunction and exposure of endothelial and smooth muscle cells [13]. This is a complex process that causes the initial pathophysiological changes of vascular damage involving cellular and other extracellular matrix elements of the vascular wall [14].

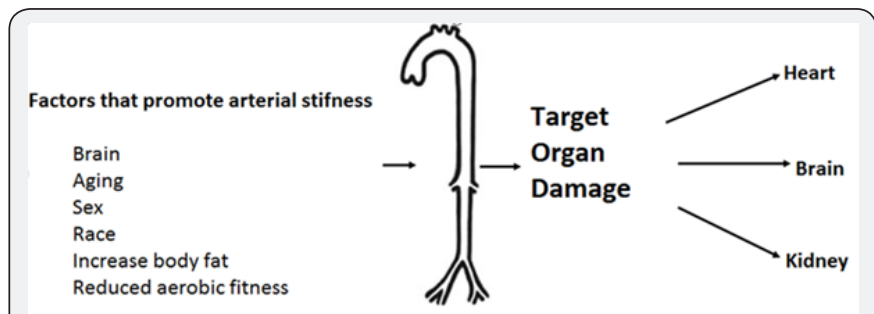

Figure 1: Epidemioogical contributors to arterial with potential implications for target organ damage. Adapted from Fleenor and Berrones [46].

Arterial stiffness is associated with increased collagen turnover and metalloproteinase activity [15-17] as well as a reduction in elastin with increased collagen deposition in the arterial wall that lead to middle layer thickening and formation of the atherosclerotic plaque [14].

Infection and inflammatory mechanisms are also involved with increasing circulating levels of phospholipase A2 [18], interleukin 1b [19] and Chlamydia pneumoniae [20]. Neurohormonal and inflammatory markers including renin-angiotensin-aldosterone system, C-reactive protein, platelet activation and apolipoprotein E deficiency $[21,22]$ have also been implicated. 


\section{Pulse wave}

When the normal heart contracts during systole, it generates a pulse wave that is transmitted along the arteries. This wave is reflected by each bifurcation or other irregularities that it encounters and is then reflected back to its starting point- the heart [23].

In a system with preserved compliance, this wave is reflected back to the heart during diastole resulting in a rise in coronary perfusion pressure and a decrease in systolic blood pressure (BP) [23]. When aortic stiffness is increased, the pulse wave propagates backward prematurely in the cardiac cycle during systole and consequently leads to increased post-load, prolonged ventricular ejection, reduced oxygen delivery to the tissues and increased metabolic ventricular demand [24-26].

\section{Arterial stiffness and coronary artery disease}

Arterial stiffness is a manifestation of the atherosclerotic process and usually precedes the formation of obstructive plaques. It is thus an early marker of coronary artery disease (CAD) (Figure 2). Assessment of the arteries using non-invasive measurements including pulse wave velocity (PWV) has allowed to identify patients at higher cardiovascular risk. The Conduit Artery Functional Endpoint (CAFE) sub study [27] of the Anglo-Scandinavian Cardiovascular Outcomes Trial (ASCOT) [28] reported that hypertensive patients with lower central BP (measured by radial artery applanation tonometry and PWV) showed fewer cardiovascular outcomes than those with apparently controlled BP in peripheral measurements but with high central BP levels.

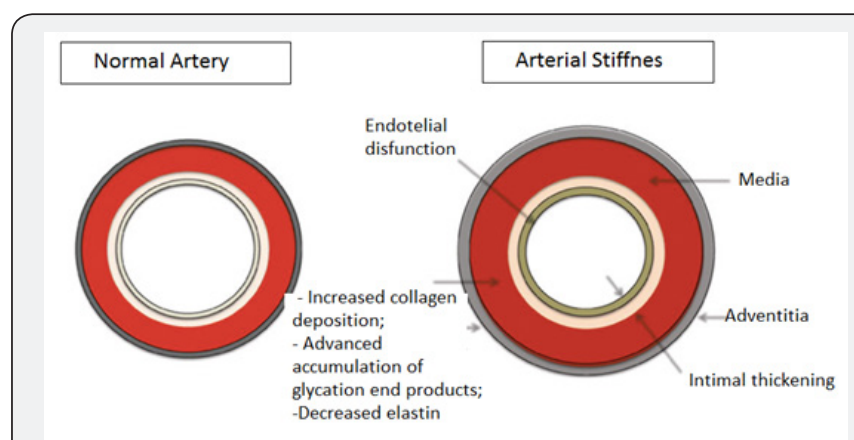

Figure 2: Multiple causes of arterial stiffness with aging and disease. Adapted from Fleenor and Berrones [46].

Other authors have investigated the correlation between CAD and aortic stiffness assessed by PWV and augmentation index (AIx). The Framingham Heart Study assessed PWV, pulse wave reflection (AIx, brachial pressure amplification) and central pulse pressure in 2,232 patients and correlated these measures with major cardiovascular outcomes including myocardial infarction, stroke, unstable angina and heart failure. The multivariate analysis showed that patients with higher PWV values had 48\% higher risk of cardiovascular events regardless of other risk factors associated $(p=0.002)$. The other aortic stiffness measurements assessed did not show to be as valuable [29].
A cohort study from China (2011) [30] evaluated 706 asymptomatic patients for the association between aortic stiffness measurements as assessed by ankle brachial PWV and coronary atherosclerosis as assessed by coronary computed tomography angiography (CCTA). The multivariate logistic regression analysis revealed that the cut-off $\mathrm{PWV}$ value at $14-18 \mathrm{~m} / \mathrm{s}$ had an odds ratio (OR) of 3.16 for the association with coronary atherosclerosis $(\mathrm{p}<0.001)$.

Several other studies have demonstrated the association of different arterial stiffness measurements with CAD. Weber et al. [31] evaluated a cohort of 465 Austrian men with CAD undergoing coronary angiography and its correlation with aortic stiffness measurements (PWV, AIx and augmentation pressure). They found a positive associated between high AIx and CAD (OR 4.06) [27]. Byung-Hee $\mathrm{Oh}$ et al. [32] assessed the association of the cardioankle vascular index (CAVI) and the presence of calcification and coronary stenosis detected by CCTA. They reported an association between CAVI and $>50 \%$ coronary stenosis (OR 2.8; p=0.032) [31].

To support the use of arterial stiffness measurements as markers for primary prevention in target populations, two studies examined these measurements in elderly patients and patients with type 2 diabetes mellitus (DM2). Gaszner et al. conducted a case-control study to assess PWV and AIx in two different groups of cardiovascular patients: DM2 and CHD. After stratification by gender and age, BP and heart rate, they found a significant association of CAD with PWV $(\mathrm{p}<0.01)$ and AIx $(\mathrm{p}<0.5)$. Interestingly, after they compared the results of patients with DM2 with healthy controls, only increased PWV values remained significant $(\mathrm{p}<0.05)$, which may suggest different outcomes depending on the methodology used to assess arterial stiffness [32]. Similarly, in a case-control study, Po-Chang Wang et al. [33] found a relationship of aortic stiffness with CAD and aging (elderly individuals over 65 years). They assessed brachial-ankle PWV measurements and found a significant relationship between PWV and the presence of CAD in elderly patients (OR 1.097; $p=0.026$ ) [34].

The use of arterial stiffness measurements as indicators for secondary prevention as an additional risk stratification approach has gained increasing ground in recent research. For more effective non-invasive risk stratification of patients with suspected or established CHD, several studies have investigated the correlation between aortic stiffness measures and severity of CAD.

Yoshikawa et al. [35] demonstrated a relationship between aortic stiffness and coronary reserve flow in patients with CAD. They found a significant correlation of increasing PWV measurements and number of damaged coronary vessels [35]. Xiong et al. [36] examined in a cohort of 321 patients with suspected CAD the relationship between brachial-ankle PWV and severity of CAD as assessed by the SYNTAX score and found a 
significant positive relationship with PWV and corrected measures by the SYNTAX score (OR 4.13; p<0.001) [36]. Moreover, Chung et al. [37] evaluated the relationship between aortic stiffness and the SYNTAX score. In their study, brachial-ankle PWV was a major predictor of CAD (OR 1.05) and correlated with the severity of CAD as assessed by the SYNTAX score [37].

To explore an association with severity of CAD, Duman et al. [38] assessed arterial stiffness by measuring carotid-femoral PWV and its relation with the extent of CAD (as assessed by Gensini scores). There was a significant positive relationship with the variables studied $(\mathrm{p}<0.001)$; and the PWV cut-off of $7.3 \mathrm{~m} / \mathrm{s}$ showed a sensitivity of $83 \%$ and a specificity of $86 \%$ for CAD diagnosis [38].

Regarding patients with coronary stenosis undergoing angioplasty, Mahfouz et al. [39] reported a positive correlation between arterial stiffness measures and intra-stent restenosis within one year of follow-up after angioplasty [39]. In contrast, in a more recent retrospective observational study, Do-Sun Lim et al. did not find any correlation between aortic stiffness measures (aortic-ankle stiffness and AIx) and CAD among patients with prior angioplasty [40]. The (Table 1) summarizes the studies assessing arterial stiffness and CAD [41-46].

Table 1: Arterial stiffness and coronary artery disease.

\begin{tabular}{|c|c|c|c|c|}
\hline Ss Author & Journal & Study Design & Method & Outcome \\
\hline Weber et al. [32] & Circulation & Coorte & VOP, Alx e AP & Relationship with CAD \\
\hline Sharma et al. [40] & Indian Heart Journal & Case-Control & Alx e AP & Relationship with CAD \\
\hline Liu et al. [30] & Atherosclerosis and Thrombosis & Coorte & PWV ankle-brachial & $\begin{array}{l}\text { Association with coronary } \\
\text { stenosis }\end{array}$ \\
\hline Xiong et al. [35] & Journal of Atherosclerosis and Thrombosis & Coorte & PWV ankle-brachial & $\begin{array}{c}\text { Association with CAD } \\
\text { severity }\end{array}$ \\
\hline Park et al. [32] & Journal of Atherosclerosis and Thrombosis & Coorte & $\begin{array}{c}\text { Ankle-brachial vascular } \\
\text { index (CAVI) }\end{array}$ & Relationship with CAD \\
\hline Lenkey et al. [33] & Physiological Research & Case-control & PWV e Alx & Relationship with CAD \\
\hline Fukuda et al. [34] & Heart Journal & Coorte & PWV ankle-brachial & $\begin{array}{l}\text { Association with CAD } \\
\text { severity }\end{array}$ \\
\hline Zhang et al. [41] & Chinese Medical Journal & Case-control & PWV & Relationship with CAD \\
\hline Chung et al. [36] & The American Journal of Medical Science & Cross sectional & PWV ankle-brachial & $\begin{array}{l}\text { Relationship with CAD and } \\
\text { CAD severity }\end{array}$ \\
\hline Chung et al. [42] & Clinical Interventions Aging & Cross sectional & PWV ankle-brachial & $\begin{array}{c}\text { Association with CAD } \\
\text { severity }\end{array}$ \\
\hline Joo et al. [39] & BMC Cardiovascular Disorders & Cross sectional & PWV ankle brachial, Alx & Relationship with CAD \\
\hline Mahfouz et al. [38] & Echocardiography & Coorte & $\begin{array}{l}\text { strain, distensibility and } \\
\text { aortic stifness }\end{array}$ & $\begin{array}{l}\text { Relationship with CAD and } \\
\text { re stenosis intra stent }\end{array}$ \\
\hline Duman et al. [37] & Acta Cardiologica & Coorte & PWV & $\begin{array}{c}\text { Relationship with CAD and } \\
\text { disease severity }\end{array}$ \\
\hline Watanabe et al. [43] & Clinical and experimental Hypertension & Coorte & Alx & $\begin{array}{l}\text { Association with coronary } \\
\text { calcification }\end{array}$ \\
\hline Vlachopoulos et al. [44] & Atherosclerosis & Review & & \\
\hline Whelton et al. [45] & Hypertension & Review & & \\
\hline
\end{tabular}

PWV: Pulse Wave Velocity; Alx: Augmentation Index; AP: Augmentation Pressure.

In conclusion, arterial stiffness can be understood as a pathophysiologic aging process of arteries that is strongly correlated with known major cardiovascular risk factors. Arterial stiffness measurements may have important clinical implications as evidence supports their usefulness for identifying patients at higher risk for major cardiovascular events. Recent studies have also pointed to a relationship of these measurements and established coronary disease, and it may thus help identifying patients with high risk of cardiovascular events or more extensive disease requiring more aggressive clinical management. Arterial stiffness assessments should be interpreted carefully in view of different measurement approaches and devices used in studies designed to validate their usefulness in research and clinical practice.

\section{References}

1. Costantino S, Paneni F, Cosentino F (2016) Ageing, metabolism and cardiovascular disease. J Physiol 594(8): 2061-2073.

2. Palombo C, Kozakova M (2016) Arterial stiffness, atherosclerosis and cardiovascular risk: Pathophysiologic mechanisms and emerging clinical indications. Vascular Pharmacol 77: 1-7.

3. McEniery CM, Yasmin, Maki-Petaja KM, McDonnell BJ, Munnery M, et al. (2010) Anglo-Cardiff Collaboration Trial Investigators. The impact 
of cardiovascular risk factors on aortic stiffness and wave reflections depends on age: the Anglo-Cardiff Collaborative Trial (ACCT III). Hypertension 56(4): 591-597.

4. Wu MY, Li CJ, Hou MF, Chu PY (2017) New Insights into the Role of Inflammation in the Pathogenesis of Atherosclerosis. Int J Mol Sci 18(10): 2034

5. Shirwany NA, Zou MH (2010) Arterial stiffness: a brief review. Acta Pharmacol Sin 31(10): 1267-1276.

6. Laurent S, Cockcroft J, Van Bortel L, Boutouyrie P, Giannattasio C, et al (2006) Expert consensus document on arterial stiffness: methodological issues. Eur Heart J 27(21): 2588-2605.

7. de Oliveira Alvim R, Santos PC, Musso MM, de Sá Cunha R, Krieger JE, et al. (2013) Impact of diabetes mellitus on arterial stiffness in a representative sample of an urban Brazilian population. Diabetol Metab Syndr 5(1): 45.

8. Tarnoki A, Tarnoki DL, Godor E, Littvay L, Horvath T, et al. (2015) Relationship of coronary atherosclerosis with arterial stiffness and central systolic blood pressure. J Hypertens 33(Suppl 1): e29.

9. Chue CD, Townend JN, Steeds RP, Ferro CJ (2010) Arterial stiffness in chronic kidney disease: causes and consequences. Heart 96(11): 817823

10. Naka KK, Papathanassiou K, Bechlioulis A, Kazakos N, Pappas K, et al. (2012) Determinants of vascular function in patients with type 2 diabetes. Cardiovasc Diabetol 11: 127.

11. Cecelja M, Chowienczyk P (2009) Dissociation of aortic pulse wave velocity with risk factors for cardiovascular disease other than hypertension: a systematic review. Hypertension 54(6): 1328-1336.

12. Pizzi O, Brandão AA, Magalhães MEC, Pozzan R, Brandão AP (2006) Velocidade de onda de pulso - o método e suas implicações prognósticas na hipertensão arterial. Rev Bras Hipertens 13(1): 59-62.

13. Amaya R, Pierides A, Tarbell JM (2015) The interaction between fluid wall shear stress and solid circumferential strain affects endothelial gene expression. PloS One 10(7): e0129952.

14. Alvim RO, Santos PCJL, Bortolotto LA, Mill JG, Pereira AC (2017) Arterial Stiffness: Pathophysiological and Genetic Aspects. Int J Cardiovasc Sci 30(5): 433-441.

15. Ikonomidis I, Kadoglou N, Tsiotra PC, Kollias A, Palios I, et al. (2012) Arterial stiffness is associated with increased monocyte expression of adiponectin receptor mRNA and protein in patients with coronary artery disease. Am J Hypertens 25(7): 746-755.

16. McNulty M, Mahmud A, Spiers P, Feely J (2006) Collagen type-I degradation is related to arterial stiffness in hypertensive and normotensive subjects. J Hum Hypertens 20(11): 867-873.

17. Chatzikyriakou SV, Tziakas DN, Chalikias GK, Stakos DA, Thomaidi AK, et al. (2008) Serum levels of collagen type-I degradation markers are associated with vascular stiffness in chronic heart failure patients. Eur J Heart Fail 10(12): 1181-1185.

18. Ikonomidis I, Kadoglou N, Tritakis V, Paraskevaidis I, Dimas K, et al. (2014) Association of Lp-PLA2 with digital reactive hyperemia, coronary flow reserve, carotid atherosclerosis and arterial stiffness in coronary artery disease. Atherosclerosis 234(1): 34-41.

19. Ikonomidis I, Tzortzis S, Andreadou I, Paraskevaidis I, Katseli C, et al. (2014) Increased benefit of interleukin-1 inhibition on vascular function, myocardial deformation, and twisting in patients with coronary artery disease and coexisting rheumatoid arthritis. Circ Cardiovasc Imaging 7(4): 619-628.

20. Pitiriga V, Lekakis J, Kotsis V, Protogerou A, Ikonomidis I, et al. (2006) Arterial stiffness and chlamydia pneumoniae infection in coronary artery disease. Is there a link? Scand Cardiovasc J 40(5): 285-290.
21. Gardier S, Vincent M, Lantelme P, Rial M0, Bricca G, et al. (2004) A1166C polymorphism of angiotensin II type 1 receptor, blood pressure and arterial stiffness in hypertension. J Hypertens 22(11): 21352142.

22. Lajemi M, Gautier S, Poirier O, Baguet JP, Mimran A, et al. (2001) Endothelin gene variants and aortic and cardiac structure in never-treated hypertensives. Am J Hypertens 14(8 Pt 1): 755-760.

23. Ikonomidis I, Makavos G, Lekakis J (2015) Arterial stiffness and coronary artery disease. Curr Opin Cardiol 30(4): 422-31.

24. Leung MC, Meredith IT, Cameron JD (2006) Aortic stiffness affects the coronary blood flow response to percutaneous coronary intervention. Am J Physiol Heart Circ Physiol 290(2): 624-630.

25. Fukuda D, Yoshiyama M, Shimada K, Yamashita H, Ehara S, et al. (2006) Relation between aortic stiffness and coronary flow reserve in patients with coronary artery disease. Heart 92(6): 759-762.

26. Ikonomidis I, Lekakis J, Papadopoulos C, Triantafyllidi H, Paraskevaidis I, et al. (2008) Incremental value of pulse wave velocity in the determination of coronary microcirculatory dysfunction in never treated patients with essential hypertension. Am J Hypertens 21(7): 806-813.

27. Williams B, Lacy PS, Thom SM, Cruickshank K, Stanton A, et al. (2006) Differential impact of blood pressure-lowering drugs on central aortic pressure and clinical outcomes: principal results of the Conduit Artery Function Evaluation (CAFE) study. Circulation 113(9): 1213-1225.

28. Ostergren J, Poulter NR, Sever PS, Dahlöf B, Wedel H, et al. (2008) The Anglo-Scandinavian Cardiac Outcomes Trial: blood pressure-lowering limb: effects in patients with type II diabetes. J Hypertens 26(11): 2103-2111.

29. Mitchell GF, Hwang SJ, Vasan RS, Larson MG, Pencina MJ, et al. (2010) Arterial stiffness and cardiovascular events: The Framingham Heart Study. Circulation 121(4): 505-511.

30. Liu CS, Li CI, Shih CM, Lin WY, Lin CH, et al. (2011) Arterial stiffness measured as pulse wave velocity is highly correlated with coronary atherosclerosis in asymptomatic patients. J Atheroscler Thromb 18(8): 652-658.

31. Weber T, Auer J, O’Rourke MF, Kvas E, Lassnig E, et al. (2004) Arterial Stiffness, Wave Reflections, and the Risk of Coronary Artery Disease. Circulation 109(2): 184-189.

32. Park JB, Park HE, Choi SY, Kim MK, Oh BH (2013) Relation between Cardio-ankle vascular index and coronary artey calcification or stenosis in asymptomatic subjects. J Atheroscler Thromb 20(6): 557-567.

33. Chung CM, Tseng YH, Lin YS, Hsu JT, Wang PC (2015) Association of brachial-ankle pulse wave velocity with atherosclerosis and presence of coronary artery disease in older patients. Clin Interv Aging 10: 1369-1375.

34. Lenkey Z, Illyés M, Böcskei R, Husznai R, Sárszegi Z, et al. (2014) Comparison of Arterial Stiffness Parameters in Patients With Coronary Artery Disease and Diabetes Mellitus Using Ateriograph. Physiol Res 63(4): 429-437.

35. Fukuda D, Yoshiyama M, Shimada K, Yamashita H, Ehara S, et al. (2006) Relation between aortic stiffness and coronary flow reserve in patients with coronary artery disease. Heart 92(6): 759-762.

36. Xiong Z, Zhu C, Zheng Z, Wang M, Wu Z, et al. (2012) Relationship between arterial stiffness assessed by brachial-ankle pulse wave velocity and coronary artery disease severity assessed by the SYNTAX score. J Atheroscler Thromb 19(11): 970-976.

37. Chung CM, Yang TY, Lin YS, Chang ST, Hsiao JF, et al. (2014) Relation of arterial stiffness assessed by brachial-ankle pulse wave velocity to complexity of coronary artery disease. Am J Med Sci 348(4): 294-299. 
38. Duman 00, Goldeli O, Gursul E, Baris N, Ozpelit E, et al. (2015) The value of aortic pulse wave velocity in predicting coronary artery disease diagnosis and severity. Acta Cardiol 70(3): 315-322.

39. Mahfouz RA, Abdulmoneim A, Abduo M, Elawady W (2013) The Relation of Aortic Stiffness and In-Stent Restenosis in Patients Undergoing Percutaneous Coronary Stenting. Echocardiography 30(5): 582-587.

40. Joo HJ, Cho SA, Cho JY (2017) The Relationship between Pulse Wave Velocity and Coronary Artery Stenosis and Percutaneous Coronary Intervention: a retrospective observational study. BMC Cardiovasc Disord 17(1): 45 .

41. Sharma KH, Sharma N, Shah K, Patil S (2018) Impact of coronary artery disease on augmentation index as measured by estimated centra blood pressure: A case control study in Asian Indians. Indian Heart J 70(5): 615-621.

42. Zhang Y, Ye P, Luo L, Bai Y, Xu R, et al. (2014) Association between arterial stiffness and risk of coronary artery disease in a community-based population. Chin Med J (Engl) 127(22): 3944-3947.

43. Watanabe N, Kurisu S, Sumimoto Y, Ikenaga H, Shimonaga T, et al (2017) Use of the augmentation index from applanation tonometry of the radial artery for assessing the extent of coronary artery calcium as assessed by coronary computed tomography. Clin Exp Hypertens 39(4): 355-360

44. Vlachopoulos C, Xaplanteris P, Aboyans V, Brodmann M, Cífková R, et al. (2015) The role of vascular biomarkers for primary and secondary prevention. A position paper from the European Society of Cardiology Working Group on peripheral circulation: Endorsed by the Association for Research into Arterial Structure and Physiology (ARTERY) Society. Atherosclerosis 241(2): 507-532

45. Whelton PK, Carey RM, Aronow WS, Casey DE, Collins KJ, et al. (2018) ACC/ AHA/ AAPA/ ABC/ ACPM/ AGS/ APhA/ ASH/ ASPC/ NMA/ PCNA Guideline for the Prevention, Detection, Evaluation, and Management of High Blood Pressure in Adults: A Report of the American College of Cardiology/ American Heart Association Task Force on Clinical Practice Guidelines. J Am Coll Cardiol 71(6): 127-248.

46. Fleenor BS, Berrones AJ (2015) Arterial Stiffness - Implications and Interventions. Springer Briefs in Physiology.

Your next submission with Juniper Publishers
will reach you the below assets
- Quality Editorial service
- Swift Peer Review
- Reprints availability
- E-prints Service
- Manuscript Podcast for convenient understanding
- Global attainment for your research
- Manuscript accessibility in different formats
( Pdf, E-pub, Full Text, Audio)
- Unceasing customer service
Track the below URL for one-step submission
https://juniperpublishers.com/online-submission.php

